\title{
A Rapid Procedure for the Isolation of RNA from High-phenolic-containing Tissues of Pecan
}

\author{
Amnon Levi', Glenn A. Galau', and Hazel Y. Wetzstein \\ University of Georgia, Athens, GA 30602
}

Additional index words. Carya illinoinensis, nucleic acid, embryos

\begin{abstract}
A simple and efficient protocol is reported for the isolation of RNA from embryos and leaves of pecan [ Carya illinoinensis (Wangenh.) K. Koch]. The method relies on suppression of the polyphenols from interaction with the RNA and their rapid removal from the homogenate by chloroform extraction. This method produced abundant amounts of high-quality RNA. This protocol is likely to be useful for Juglandaceous species and other recalcitrant plants with high levels of phenolic compounds.
\end{abstract}

Although immense advances in plant biotechnology have been made in recent years, there are few methods available for isolation of nucleic acids from nut crops. Due to the interference from plant secondary compounds, standard methods often require ma-

Received for publication 30 Dec. 1991. Accepted for publication 30 June 1992. WC thank D.W. Hughes for his constructive advice. This study was supported by a grant from the University of Georgia Research Foundation. The cost of publishing this paper was defrayed in part by the payment of page charges. Under postal regulations, this paper therefore must be hereby marked advertisement solely to indicate this fact.

'Dept. of Horticulture.

${ }^{2}$ Dept. of Botany. jor modifications for the isolation of nucleic acids of high quality and sufficient quantity (Baker et al., 1990; Hughes and Galau, 1988; Logemann et al., 1987; Van Driessche et al., 1984). There are many applications of biotechnology for the genetic improvement of perennial fruit and nut crops (for review see Scorza, 1991). An efficient and reproducible method for isolation of nucleic acid is a prerequisite for the application of such technologies.

The preparation of RNA from plant tissue requires vigorous homogenization and disruption of cells to liberate the nucleic acids. Under these conditions, cell components such as lipids, proteins, polysaccharides, and secondary compounds that are compartmental- 


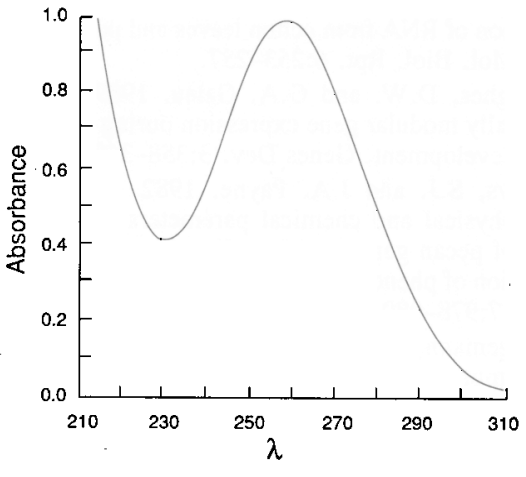

Fig. 1. Spectrum of RNA isolated from mature pecan embryo cotyledons. The ratio of absorbance at wave lengths $(\lambda) 260 \mathrm{~nm}$ and $280 \mathrm{~nm}$ is 1.9 .

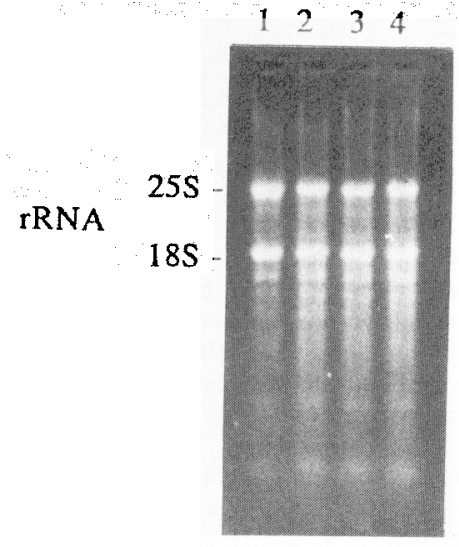

Fig. 2. A $1.8 \%$ agarose, $6 \%$ formaldehyde gel containing RNA $(2 \mu \mathrm{g} / \mathrm{lane})$ isolated from pecan somatic embryos (lanes 1,2, and 3) and leaves (lane 4). Electrophoresis conditions and staining of RNA with ethidium bromide were both as described by Sambrook et al. (1989).

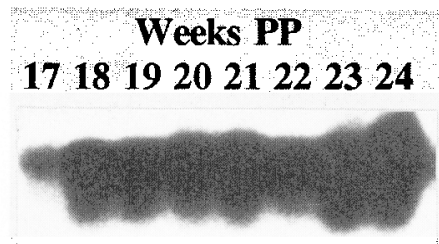

Fig. 3. Autoradiogram of a northern blot. Total RNA was isolated from pecan zygotic embryos at late developmental stages, 17 to 24 weeks post-pollination (PP). The RNA ( $2 \mu \mathrm{g} / \mathrm{lane})$ was electrophoresed on a 1.8\% agarose, 670 formaldehyde gel, as in Fig. 2, and transferred onto a GeneScreen membrane (Du pent.New England Nuclear, Boston). The membrane was then washed, air-dried, irradiated with $W$ light, and heated for $1 \mathrm{~h}$ at $80 \mathrm{C}$ under vacuum. The membrane was hybridized at $\mathrm{Tm}-15 \mathrm{C}$, with the 32P-labeled insert from the cotton cDNA clone E6 (Hughes and Galau, 1989). Methods are described in Galau et al. (1986) and Sambrook et al. (1989)

ized within organelles and cytoplasm are released from the ruptured cells and can become oxidized; they then irreversibly react with nucleic acids (Hughes and Galau, 1988; Logemann et al., 1987; Loomis, 1974; Van Driessche et al., 1984), Fruits and leaves of pecan and related species in the Juglanda-
Table 1. Yield of RNA from various pecan tissues.

\begin{tabular}{lc}
\hline Tissue & $\begin{array}{c}\text { RNA yieldz } \\
\text { (mg/g lyophilized } \\
\text { tissue) }\end{array}$ \\
\hline Young leaves & $10.0-12.0$ \\
Somatic embryo cotyledons & $1.6-1.7$ \\
Zygotic embryo cotyledons & \\
Cotyledon expansion stage & $0.8-0.9$ \\
Maturation stage & $0.6-0.8$ \\
Mature embryo & $0.4-0.6$ \\
Early germination stage & $0.5-0.6$ \\
Late germination stage & $0.2-0.3$ \\
\hline
\end{tabular}

${ }^{2}$ RNA yields are a range from two to four replications.

ceae contain several phenolic compounds such as juglone (5-hydroxy-1,4-naphthoquinone), tannins, and isoquercitrin (Muller and Leistner, 1978). Together, these compounds can comprise $\approx 4 \%$ of the dry weight of mature embryos and up to $52 \%$ of the dry weight of the tissue surrounding the mature pecan embryo (Kays and Payne, 1982). Pecan leaves contain high concentrations of phenolic compounds in the vacuoles (Wetzstein and Sparks, 1983), and their presence is evident as an instantaneous wound response.

In our early experiments with mature pecan embryos, phenol and phenol : chloroform were used as chaotropic and deproteinizing agents. The isolation of RNA was frequently hampered due to the appearance of phenolic-like compounds likely resulting from reaction of the pecan polyphenols with the phenol solvent (Loomis, 1974; Van Driessche et al., 1984). These phenolic-like compounds often copurified with the RNA, and rigorous attempts to remove them from the RNA solution either failed or resulted in a low RNA yield. Low or variable RNA yields were also obtained when we used several variations of protocols that rapidly removed cell components from the homogenate by direct centrifugation (Baker et al., 1990) or by precipitation with high salt concentrations (Hughes and Galau, 1988).

The successful method described here relies on the suppression of the formation of oxidized polyphenolic compounds in the initial extraction solution and the rapid removal of cell components while ribonucleases are being deproteinized. The initial extraction buffer used here contained several detergents and inhibitors of polyphenols (Hughes and Galau, 1988) in addition to 2-mercaptoethanol and polyvinylpyrrolidone (PVP). The present method employed chloroform as the sole chaotropic agent, followed by highsalt precipitations to remove most of the DNA, neutral polysaccharides, and residual protein. This method resulted in high yields of intact RNA of sufficient purity for blots and cDNA synthesis.

Plant material. Fruits were collected at various developmental stages from pecan trees growing at the horticulture farm in Watkinsville, Ga. Fruits were kept on ice, and embryos were removed within $1.5 \mathrm{~h}$ of collection. Somatic embryos were collected from repetitive somatic embryogenic cultures (Wetz- stein et al., 1989). Zygotic or somatic embryos were placed in a $15-$ or $50-\mathrm{ml}$ plastic conical tube and frozen with liquid nitrogen and immediately lyophilized or temporarily stored at $-80 \mathrm{C}$ before lyophilization. Young leaves were collected and frozen at $-80 \mathrm{C}$ until extraction.

Glassware and solutions. All glass- and plasticware was soaked in $0.1 \%$ diethylpyrocarbonate (DEPC) for 30 min to inhibit RNase activity. Solutions were prepared from stocks that had been treated with $0.1 \%$ DEPC, filtered through $0.45-\mu \mathrm{m}$ nitrocellulose filters, and autoclave (Sambrook et al., 1989).

The homogenization buffer contained: 200 mM tris $\cdot \mathrm{HCl}, \mathrm{pH} 8.5$ at room temperature, $1.5 \%(\mathrm{w} / \mathrm{v})$ lithium dodecylsulfate, $300 \mathrm{~mm}$ $\mathrm{LiCl}, 10 \mathrm{~mm} \mathrm{Na}$ EDTA, 1.5\% (w/v) sodium deoxycholate, and $1.5 \%(\mathrm{v} / \mathrm{v})$ Nonidet P-40 (Sigma, St. Louis). After DEPC treatment, the buffer was stored at -20C. Just before homogenization, thiourea, aurintricarboxylic acid, and dithiothreitol (DTT) were added to $0.5,1$, and $10 \mathrm{~mm}$, respectively (Hughes and Galau, 1988). Also added were 2-mercaptoethanol to $75 \mathrm{~mm}$ and soluble (molecular weight 360,000 ) and insoluble polyvinylpyrrolidone (PVP), each adjusted to $2 \%(\mathrm{w} / \mathrm{v})$.

Extraction protocol. All manipulations were performed at $4 \mathrm{C}$. Lyophilized tissue $(0.33 \mathrm{~g})$ was homogenized in $5 \mathrm{ml}$ homogenization buffer using a dual tissue grinder. The homogenate was transferred to a $15-\mathrm{ml}$ polypropylene conical centrifuge tube. Five milliliters of chloroform was added, and the tube was shaken thoroughly for 5 min to form a white emulsion. To improve subsequent phase separation, another $5 \mathrm{ml}$ chloroform was added and gently mixed. The contents were centrifuged for $15 \mathrm{~min}$ at $2500 \times \mathrm{g}$. The upper aqueous phase was transferred to a new conical tube and re-extracted for $5 \mathrm{~min}$ with $5 \mathrm{ml}$ chloroform. Following $15 \mathrm{~min}$ centrifugation at $2500 \times \mathrm{g}$, the upper aqueous phase was transferred to a new conical tube and mixed with $0.5 \mathrm{ml}$ of $3 \mathrm{M} \mathrm{NaCl}$ and 10 $\mathrm{ml}$ ethanol. The mixture was stored at -20C for $1 \mathrm{~h}$, then centrifuged for $15 \mathrm{~min}$ at $4000 \mathrm{x}$ $\mathrm{g}$. The pellet was dissolved in $500 \mu \mathrm{l}$ of TE1 (50 mu tris $\cdot \mathrm{HCl}, 10 \mathrm{~mm}$ sodium EDTA, $\mathrm{pH}$ 8.0), transferred to a $1.5-\mathrm{ml}$ microfuge tube, and clarified by $10 \mathrm{~min}$ centrifugation at $12,000 \times \mathrm{g}$. The supernatant was transferred to a new $1.5-\mathrm{ml}$ microfuge tube, and $50 \mu \mathrm{l}$ of $3 \mathrm{M} \mathrm{NaCl}$ and $275 \mu \mathrm{l}$ of isopropanol were added. Contents were mixed and stored at $-20 \mathrm{C}$ for $1 \mathrm{~h}$ before $10 \mathrm{~min}$ centrifugation at $14,000 \times \mathrm{g}$. Isopropanol was drained, and the pellet was washed with $400 \mu \mathrm{l}$ of $70 \%$ ethanol and drained. The pellet was dissolved in $300 \mu \mathrm{l}$ of TE1, and $100 \mu \mathrm{l}$ of $8 \mathrm{M}$ $\mathrm{LiCl}$ was added to bring the $\mathrm{LiCl}$ concentration to $2 \mathrm{M}$. The mixture was incubated for $12 \mathrm{~h}$ on ice and centrifuged at $14,000 \times \mathrm{g}$ for $10 \mathrm{~min}$. The pellet was dissolved in 300 $\mu \mathrm{l}$ of TE1 and $450 \mu \mathrm{l}$ of $5 \mathrm{M}$ potassium acetate was added. The mixture was incubated for $5 \mathrm{~h}$ on ice, and then centrifuged as above. The pellet was dissolved in $300 \mu \mathrm{l}$ of TE1, mixed with $30 \mu \mathrm{l}$ of $3 \mathrm{M} \mathrm{NaCl}$ and $660 \mu$ ethanol, stored for $1 \mathrm{~h}$ at $-20 \mathrm{C}$, then 
centrifuged as above. The ethanol was drained and the pellet was carefully washed with 400 $\mu \mathrm{l}$ of $70 \%$ ethanol and centrifuged as above. The pellet was vacuum-dried and dissolved in $300 \mu \mathrm{l}$ of $10 \mathrm{~mm}$ tris $\cdot \mathrm{HCl}, 1 \mathrm{~mm}$ sodium EDTA (pH 8.0). The solution was clarified by 5 min of centrifugation at $12,000 \times \mathrm{g}$, and the supernatant was retrieved. RNA concentration was $\approx 1 \mathrm{mg} \cdot \mathrm{ml}^{-1}$.

The occasional copurification of phenolic compounds with RNA, which occurred in our early experiments, validated the requirement to vigorously prevent these compounds from interacting with RNA. High ionic strength, elevated $\mathrm{pH}$, presence of several detergents (Hughes and Galau, 1988), addition of phenolic- and tannin-binding PVP, and the antioxidants 2-mercaptoethanol and DTT together largely suppressed interaction of the phenolic compounds with nucleic acids in the initial extraction solution.

Our earlier experiments using phenol or phenol : chloroform for deproteinization of the homogenate from mature zygotic embryos, however, often resulted in low RNA yields ( 0 to $0.15 \mathrm{mg} \cdot \mathrm{g}^{-1}$ of lyophilized mature embryo tissue). This was due to coprecipitation of phenolic compounds with the RNA, following a quick browning reaction that may have resulted from interaction of pecan polyphenols with those in the phenol solvent (Loomis, 1974; Van Driessche et al., 1984). Irreversible binding of RNA to the homogenized tissue may also have occurred in the presence of phenol (Hughes and Galau, 1988). In contrast, the use of chloroform as the sole organic solvent did not result in rapid browning. Moreover, chloroform proved to be sufficient for deproteinization and for denaturation of ribonucleases. Pure nucleic acids have been obtained in previous studies with plants where chloroform was used as the main solvent for deproteinization (Murray and Thompson, 1980).

The method presented here is effective in isolation of RNA from embryogenic and leaf tissues (Table 1). Satisfactory results were obtained over a wide range of embryo developmental stages. The leaf and embryo RNA yields obtained in this study compare favorably with those obtained in other dicotyledonous species using other methods (Baker et al., 1990; Hughes and Galau, 1988; Logemann et al., 1987). RNA yield from young zygotic embryos was 1.5- and 3-fold higher than from mature embryos and embryos at late germination stages, respectively. Somatic embryos yielded twice the RNA of even the youngest zygotic embryos (Table 1). Further experiments are required to assess whether these differences in yield are due to differences in RNA content or tissue properties that affect RNA recovery.

The RNA obtained by this procedure has a normal spectrum (Fig. 1), is intact (Fig. 2), hybridizes well in blots (Fig. 3), and is suitable for the preparation of cDNA (unpublished data). This protocol is likely to be useful for preparation of nucleic acids from other species in the Juglandaceae and from recalcitrant plants that contain high levels of phenolic compounds.

\section{Literature Cited}

Baker, S. S., C.L. Rugh, and J.C. Kamalay. 1990. RNA and DNA isolation from recalcitrant plant tissue. Bio Techniques 9:268-272.

Galau, G.A., D.W. Hughes, and L. Dure III. 1986. Abscisic acid induction of cloned cotton late embryogenesis-abundant (Lea) mRNAs. Plant Mol. Biol. 7:155-170.

Hughes, D.W. and G.A. Galau. 1988. Prepara- tion of RNA from cotton leaves and pollen. Plant Mol. Biol Rpt. 6:253-257.

Hughes, D.W. and G.A. Galau. 1989. Temporally modular gene expression during cotyledon development. Genes Dev. 3:358-369.

Kays, S.J. and J.A. Payne. 1982. Analysis of physical and chemical parameters of the shell of pecan genotypes in reference to the production of phenolic plastics and resins. HortScience 17:978-980.

Logemann, J., J. Schell, and L. Willmitzer. 1987. Improved method for the isolation of RNA from plant tissues. Anal. Biochem. 163:16-20.

Loomis, W.D. 1974. Overcoming problems of phenolics and quinones in the isolation of plant enzymes and organelles. Methods Enzymol. 31:528-545.

Muller, W.-U. and E. Leistner. 1978. Aglycones and glycosides of oxygenated naphthalenes and a glycosytransferase from Juglans. Photochemistry $17: 1739-1742$.

Murray, M.G. and W.F. Thompson. 1980, Rapid isolation of high molecular weight plant DNA. Nucleic Acid Res. 8:4321-4325.

Sambrook, J., E.F. Fritsch, and T. Maniatis. 1989, Molecular cloning: A laboratory manual. 2nd ed. Cold Spring Harbor Laboratory Press, Cold Spring Harbor, N.Y.

Scorza, R. 1991. Gene transfer for genetic improvement of perennial fruit and nut crops. HortScience 26:1033-1035.

Van Driessche, E., S. Beeckmans, R. Dejaegere, and L. Kanarek. 1984. Thiourea: The antioxidant of choice for the purification of proteins from phenol-rich plant tissues. Anal Biochem. 141:184-188.

Wetzstein, H.Y. and D. Sparks. 1983. Anatomical indices of cultivar and age-related scab resistance and susceptibility in pecan leaves, J. Amer. Sot. Hort. Sci. 108:210-218.

Wetzstein, H. Y., J.R. Auk, and S.A. Merkle. 1989. Further characterization of somatic embryogenesis and plantlet regeneration in pecan (Carya illinoensis). Plant Sci. 64:193-201. 